\title{
Interaction between TP53 and XRCC1 increases susceptibility to cervical cancer development: a case control study
}

\author{
Gui-Cen Liư ${ }^{\dagger}$ Yun-Fei Zhou ${ }^{\dagger}$, Xiao-Chao Su and Jun Zhang ${ }^{*}$ (D)
}

\begin{abstract}
Background: Cervical cancer is the 4th highest cause of female reproductive tract malignancies. Multiple loci have been identified as important determinant factors for tumor susceptibility. In this report, we aimed to explore the roles of gene polymorphisms affecting $x$-ray repair cross complementing 1 (XRCC1), the tumor protein p53 (TP53), and fibroblast growth factor receptor 3 (FGFR3) in the context of susceptibility to cervical cancer. Additionally, we assessed the impact of single nucleotide polymorphism-single nucleotide polymorphism (SNP-SNP) interaction of these three genes in the context of cervical cancer risk in Chinese women.
\end{abstract}

Methods: A case-control study consisted of 340 women located in Chongqing. Of these women, 121 were diagnosed with cervical cancer, 118 served as healthy controls, and 101 were specifically recruited elderly patients above the age of 80 who showed no history of cervical cancer. Three SNPs (XRCC1 rs25487, TP53 rs1042522, and FGFR3 rs121913483) were examined using mutation analysis of mismatch amplification PCR (MAMA-PCR) on samples obtained from peripheral blood.

Results: Our results indicated that females from southwestern China all exhibited a wild-type phenotype at FGFR3 rs121913483. We also observed that the rs25487 mutation was significantly increased within the cervical cancer population. A 2-locus SNP-SNP interaction pattern (rs25487 and rs1042522) was significantly associated with cervical cancer risk (cases vs. negative controls: $\mathrm{OR}=4.63,95 \% \mathrm{Cl}=1.83-11.75$; cases vs. elderly group: $\mathrm{OR}=17.61,95 \% \mathrm{Cl}=4.34-71.50)$.

Conclusions: This is the first study to identify a novel interaction between the XRCC1 and TP53 genes that is highly associated with susceptibility to cervical cancer risk in a female population in southwestern China.

Keywords: Cervical cancer, XRCC1, TP53, FGFR3, SNP-SNP interaction

\section{Background}

Cervical cancer is the fourth most common malignant tumor of the female reproductive tract, with an estimated 528,000 new cases and 266,000 deaths occurring annually worldwide [1]. Among the less-developed nations, this disease accounts for $85 \%$ of the prevalence and $87 \%$ of the mortality [2]. Infection by Human papillomavirus (HPV) is the primary cause of the vast majority of cervical tumors [3, 4]; however, most HPV infections are temporary, and more than $90 \%$ of

\footnotetext{
* Correspondence: zhangjun1017@sohu.com

${ }^{\dagger}$ Gui-Cen Liu and Yun-Fei Zhou contributed equally to this work. Institute of Molecular Medicine and Oncology, Chongqing Medical University, Yuzhong District, Chongqing City 400016, China
}

infections are cleared by hosts within 3 years. Additionally, only a small portion of HPV-infected women develop cervical cancer [5,6]. A number of studies have shown that HPV infection alone is insufficient to cause tumorigenesis and that tumor development is triggered by the combined effects of environmental stimuli and individual genetic factors $[7,8]$. SNPs are considered to be the most widespread type of genetic variation (approximately 90\%) in the human genome [9]. Examining SNP loci in the context of patients is essential for developing effective personalized medicine [10].

Recently, numerous studies have been performed to assess the effect of SNPs on cervical cancer susceptibility [11-13]. Based on these reports and findings from

(c) The Author(s). 2019 Open Access This article is distributed under the terms of the Creative Commons Attribution 4.0 International License (http://creativecommons.org/licenses/by/4.0/), which permits unrestricted use, distribution, and 
bioinformatics studies exploring high risk factors within the Chinese population for cervical cancer, we focused our current study on crucial genes within the DNA repair and recombination pathways. Base excision repair (BER) is an important pathway that has been suggested to be crucial for the prevention of cervical cancer [14]; however, the effects of SNP-SNP interaction between genetic polymorphisms within the BER pathway on cervical cancer susceptibility remain unknown. XRCC1 is an important regulator of the BER pathway and TP53 also participates in DNA repair progression. The exact role of TP53 in the formation of cervical cancer, however, remains largely controversial [15-17]. No studies have previously reported a correlation between FGFR3 polymorphisms within the Chinese population and a genetic predisposition to cervical cancer. Also, data describing the relationships between FGFR3 polymorphisms and a genetic predisposition to cervical cancer have not been reported in China $[18,19]$. Here, the genes encoding XRCC1, TP53, and FGFR3 were chosen for our analysis.

In our current study, we aimed to integrate bioinformatics methods with samples exhibiting diverse clinical features in an effort to explore the roles of various SNPs in the pathogenesis of cervical cancer within the southwestern population of China.

\section{Methods}

\section{Subjects}

Biological specimens were collected from women of similar ethnic and geographical backgrounds in Chongqing, China. A total of 121 women (age: $42.01 \pm$ 9.4) with a history of cervical cancer were recruited from the first affiliated hospital of Chongqing Medical University. The control group consisted of 118 healthy women (age: $35.43 \pm 10.41$ ) who were selected following a regular gynecological examination. Another control group was comprised of 101 healthy elderly women with a lifelong proven absence of cervical cancer (aged: $84.5 \pm$ 2.37) (Additional file 1). The number of HPV-positive women was 140 (mean $\pm \mathrm{SD}, 60.68 \pm 1.81$ ). No more than $8(6 \%)$ patients had prior screening and $11(8 \%)$ patients in the HPV-positive group reported a history of sexually transmitted disease (STD). The number of $\mathrm{HPV}$-negative controls was 197 (mean $\pm \mathrm{SD}, 41.58 \pm$ 0.94 ), and 8 of these reported a previous history of other undetermined cervical infections (Additional file 2). Samples of $2 \mathrm{ml}$ peripheral blood were obtained from all subjects. The local ethics committee of the Chongqing Medical University approved the experimental design, clinical data collection methods, and data evaluation strategies. These procedures were carried out in accordance with the approved guidelines. Written informed consent was obtained from all participants.

\section{Gene selection}

All published literature through 31 October 2015 detailing susceptibility to cervical cancer was retrieved by text mining and obtained from the NCBI database. The keywords 'cervical cancer' and 'gene,' single nucleotide polymorphism,' 'DNA polymorphism', 'genetic polymorphism', or 'genetic variation' were used in combination to retrieve the relevant literature. Genes reported by three or more articles with enrolled sample numbers greater than 200 were considered. We e-mailed authors to obtain full text articles if these could not be downloaded from PubMed and Web of Science. According to the literature, there were 62 gene polymorphisms associated with cervical cancer risk. A protein molecular network based on these 62 genes was built by String [20]. AmiGo 2 [21] and ClusterProfiler packages were used to determine enriched GO terms (Fig. 1) [22].

\section{Isolation of genomic DNA}

MAMA-PCR was performed for genotype identification. Genomic DNA was extracted from peripheral blood samples using a Rapid Blood Genomic DNA Isolation Kit (Sangon Biotech, Shanghai, China), and extracts were stored at $-20{ }^{\circ} \mathrm{C}$ until use. DNA quantity was measured using an ultraviolet spectrophotometer at $260 \mathrm{~nm}$, and the DNA quality was assessed by agarose gel electrophoresis. The rs121913483 (C>G), rs25487 (G > A), and rs1042522 (G > C) genotypes were identified separately by MAMA-PCR and then validated by Sanger sequencing (Sangon Biotech, Shanghai, China) as described in Additional file 3: Figure S1. The PCR primers (Invitrogen, Shanghai, China) used to amplify the genes are as follows:

\begin{tabular}{|c|c|c|}
\hline Genes & Items & nucleotide sequence \\
\hline \multirow[t]{3}{*}{ FGFR3 } & F1 & 5'-CCCCCACAGAGCGCTC-3' \\
\hline & F2 & 5'-CCCCCACAGAGCGCTG-3' \\
\hline & $\mathbf{R}$ & 5'-TAGACCCAAATCCTCACGCA-3' \\
\hline \multirow[t]{3}{*}{ TP53 } & F1 & 5'-CAGAGGCTGCTCCCCG-3' \\
\hline & F2 & 5'-CAGAGGCTGCTCCCCC-3' \\
\hline & $\mathbf{R}$ & 5'-AGCCAAGGAATACACGTGGA-3' \\
\hline \multirow[t]{3}{*}{ XRCC1 } & $\mathbf{F}$ & 5'-CTCTGTCTGTCTCCCCTGTCT-3' \\
\hline & R1 & 5'-CGTGTGAGGCCTTACCTCC-3' \\
\hline & R2 & 5'-CGTGTGAGGCCTTACCTCT-3' \\
\hline
\end{tabular}

The final reaction mixture contained $50 \mathrm{ng}$ template DNA, $0.2 \mu \mathrm{L}$ Taq polymerase, $2.4 \mu \mathrm{L}$ dNTPs, $2 \mu \mathrm{L} 10 \mathrm{X}$ PCR Buffer (Takara, Japan), $50 \mathrm{nmol}$ each reverse and forward primers, $\mathrm{MgCl}_{2}$ (Takara, Japan; FGFR3, $1 \mu \mathrm{L}$; XRCC1, $1.5 \mu \mathrm{L}$; TP53, $2 \mu \mathrm{L}$ ), and double-distilled $\mathrm{H}_{2} \mathrm{O}$ 


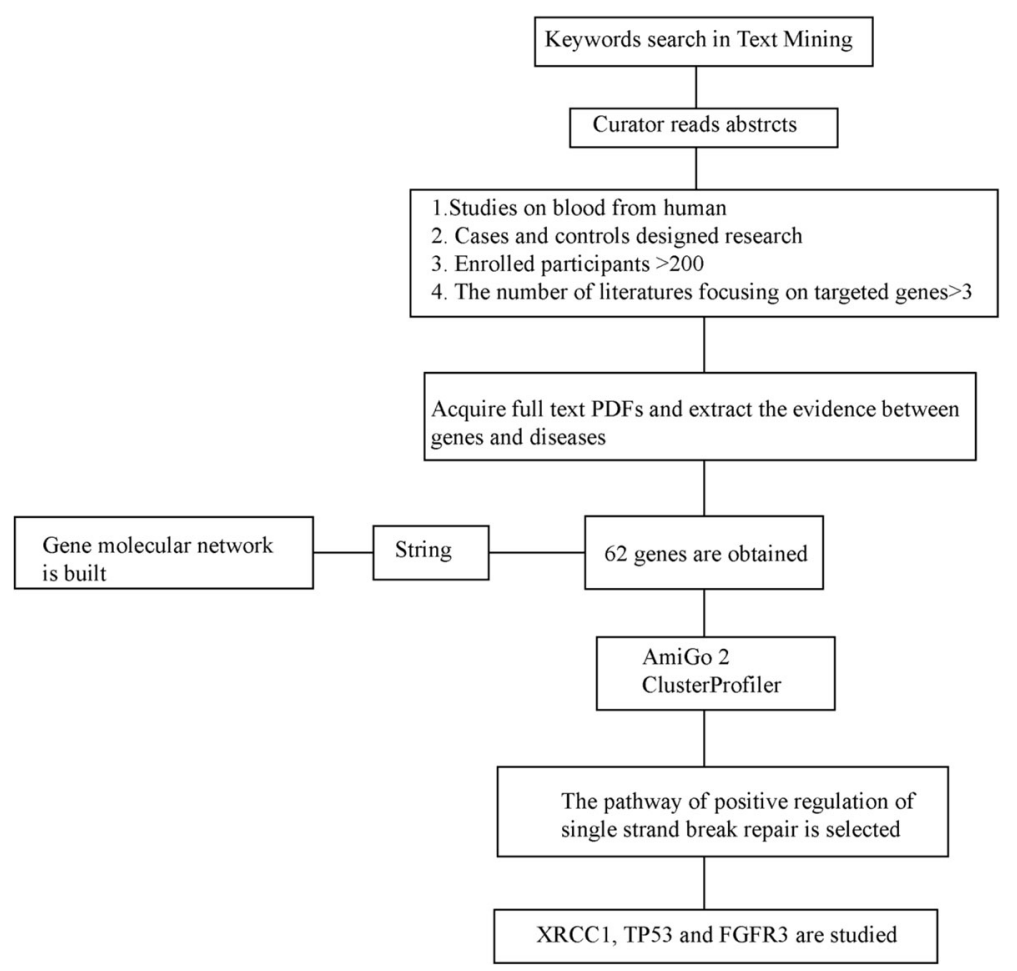

Fig. 1 schematic illustration for text mining of dominant SNPs related to pathogenesis of cervical cancer, and identified XRCC1, TP53, as well as FGFR3

at a final reaction volume of $20 \mu \mathrm{L}$. Amplification conditions for XRCC1 consisted of an initial denaturing step at $94{ }^{\circ} \mathrm{C}$ followed by 36 cycles at $94{ }^{\circ} \mathrm{C}$ for 10 s, $57^{\circ} \mathrm{C}$ for $30, \mathrm{~s}$ and $72^{\circ} \mathrm{C}$ for $1 \mathrm{~min}$. MAMA-PCR of TP53 was performed for 35 cycles at $98^{\circ} \mathrm{C}$ for $10 \mathrm{~s}$, $57{ }^{\circ} \mathrm{C}$ for $30 \mathrm{~s}$, and $72^{\circ} \mathrm{C}$ for $1 \mathrm{~min}$. PCR conditions for FGFR3 included initial denaturation at $94{ }^{\circ} \mathrm{C}$ for 5 min followed by 35 cycles at $94{ }^{\circ} \mathrm{C}$ for $30 \mathrm{~s}, 56{ }^{\circ} \mathrm{C}$ for $30 \mathrm{~s}$, and $72^{\circ} \mathrm{C}$ for $1 \mathrm{~min}$. All PCR reactions were followed by a final extension at $72{ }^{\circ} \mathrm{C}$ for $10 \mathrm{~min}$.

\section{Statistical analysis}

The mean and standard deviation (SD) was used for describing normally distributed continuous variables. Deviations from the Hardy-Weinberg equilibrium (HWE) for three SNPs were tested using a chi-square $\left(\chi^{2}\right)$ test. The association among TP53, XRCC1, and FGFR3 and the effects of these associations in the context of cervical cancer risk was studied by calculating the ORs and 95\% CIs based on $X^{2}$ analysis. The SNP-SNP interaction experiments were performed by generalized multifactor dimensionality reduction (GMDR) [23] and logistic regression using SPSS 19.0 software (SPSS Inc., Chicago, IL, USA). A $p$-value of $<0.05$ was considered to indicate significance.

\section{Results}

Identification of candidate SNPs using text mining and bioinformatics

A molecular network diagram of 62 selected genes related to increased risk of cervical cancer was constructed using String (Fig. 2a). The top three GO items showing the lowest $p$-value included regulation of DNA metabolic processes, regulation of response to DNA damage stimulus, and positive regulation of DNA metabolic processes promoting DNA single strand break repair (Fig. 2b). Here, we focused mainly on this repair pathway and selected genes important for pathway function. It has been confirmed that the XRCC1 gene plays an important role in modulating the risk for cervical cancer $[24,25]$; however, the impact of the TP53 gene on this risk is less clear. No results have yet been reported concerning the interaction between XRCC1 and TP53 in the context of cervical cancer. Additionally, the FGFR3 gene, which has no known role in cervical cancer, was chosen for subsequent analysis. In summary, based on bioinformatics studies were selected the XRCC1, TP53, and FGFR3 genes as candidates for this study.

\section{Genetic analysis}

We sequenced the three genes containing rs121913483 (C > G), rs1042522 (G > C), and rs25487 (G > A) from 121 

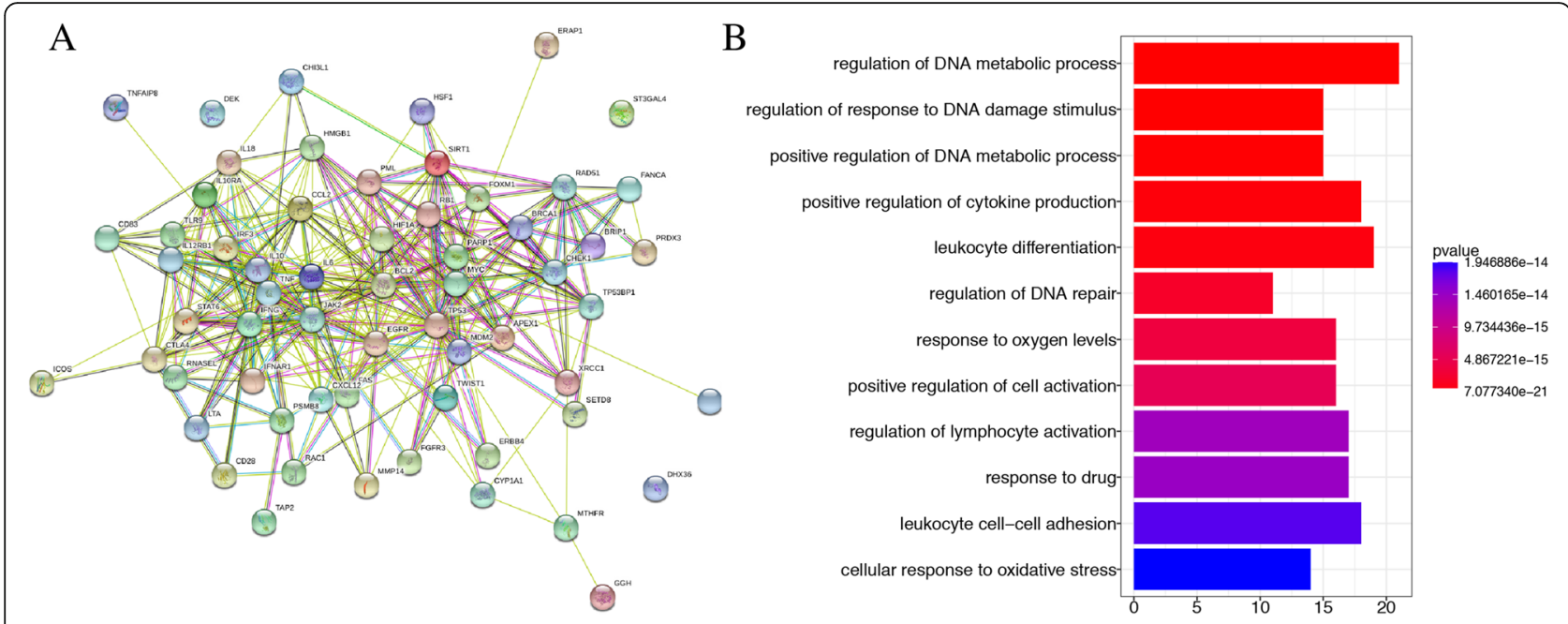

Fig. 2 Network analysis of essential protein from String (a), and pathway analysis for these 62 genes by ClusterProfiler (b)

Chinese women suffering from cervical cancer and from 219 controls. The distribution frequencies of rs1042522 and rs25487 were found to be in HWE (Table 1). No variation in rs 121913483 was found in any of the cancer cases, negative controls, or the elderly group.

A case-control study of the three SNPs was conducted to compare the cervical cancer group to the elderly control group. Table 2 illustrates the distribution of XRCC1 rs25487 and TP53 rs1042522 within the study groups. Here, we found that the minor alleles of the XRCC1 gene significantly correlated to the cervical cancer group when compared to the negative group $(\mathrm{OR}=3.43$, $95 \% \mathrm{CI}=1.50-7.85, p=0.00)$ or the elderly group $(\mathrm{OR}=3.00,95 \% \mathrm{CI}=1.26-7.10, p=0.03)$. This genotype (dominant model) conveyed a nearly 2-fold higher risk compared with that of negative controls.
No significant differences were observed among our experimental groups in regard to TP53 gene status.

\section{SNP-SNP interaction between $X R C C 1$ and TP53 polymorphisms}

To assess SNP-SNP interaction, genotypic data for the three polymorphisms detailed in this study were analyzed by GMDR and logistic regression. The SNP-SNP interaction data are summarized in Tables 3 and 4, and the genetic models are presented in Table 5 . When the rs25487 and rs1042522 status of both control groups was combined into a single analysis, logistic regression showed a clear relationship between heterogeneity in the ORs among heterozygotes $(p<0.05)$. Examining rs25487 and rs1042522 provided the best two-factor model (testing accuracy $(\mathrm{TA})=0.63, p=0.00$, cross-validation consistency $(\mathrm{CVC})=10 / 10)$, and this model was as

Table 1 The genotype distribution and H-W of XRCC1 (rs25487), TP53 (rs1042522) and FGFR3 (rs121913483)

\begin{tabular}{|c|c|c|c|c|c|c|c|c|c|c|c|c|}
\hline Variable & Alleles & Phenotype & $\mathrm{N}$ & HWE & MAF & M/M (\%) & $\mathrm{M} / \mathrm{m}(\%)$ & m/m (\%) & $\mathrm{M} / \mathrm{M}+\mathrm{M} / \mathrm{m}$ & $\mathrm{M} / \mathrm{m}+\mathrm{m} / \mathrm{m}$ & Allele M & Allele m \\
\hline \multirow[t]{3}{*}{ rs25487 } & \multirow[t]{3}{*}{$G>A$} & Cases & 121 & 0.18 & 0.40 & $47(38.9)$ & $51(42.1)$ & 23(19) & 98 & 74 & $145(59.9)$ & $97(40.1)$ \\
\hline & & NC & 118 & 0.15 & 0.25 & $70(59.3)$ & $38(32.2)$ & $10(8.5)$ & 108 & 48 & 178(75.4) & $58(24.6)$ \\
\hline & & OC & 101 & 0.45 & 0.27 & $55(54.4)$ & $37(36.6)$ & 9(9) & 92 & 46 & 147(72.8) & $55(27.2)$ \\
\hline \multirow[t]{3}{*}{ rs1042522 } & \multirow[t]{3}{*}{$G>C$} & Cases & 121 & 0.18 & 0.38 & $50(41.3)$ & $50(41.3)$ & $21(17.4)$ & 100 & 71 & 150(62) & $92(38)$ \\
\hline & & NC & 108 & 0.74 & 0.42 & $37(34.3)$ & $51(47.2)$ & $20(18.5)$ & 88 & 71 & 125(57.9) & $91(42.1)$ \\
\hline & & OC & $99^{a}$ & 0.07 & 0.44 & $35(35.4)$ & $40(40.4)$ & $24(24.2)$ & 75 & 64 & $110(55.6)$ & $88(44.4)$ \\
\hline \multirow[t]{3}{*}{ rs121913483 } & \multirow[t]{3}{*}{$G>C$} & Cases & 117 & & & 117 & 0 & 0 & & & & \\
\hline & & NC & 113 & & & 113 & 0 & 0 & & & & \\
\hline & & OC & 89 & & & 89 & 0 & 0 & & & & \\
\hline
\end{tabular}

$N$ Number, HWE Hardy-Weinberg equilibrium, MAF Minor allele frequency, NC Negative controls, OC Old controls

${ }^{a}$ The number of subjects in each group at different sites may be different due to insufficient DNA 
Table 2 The association between gene polymorphism of XRCC1 (rs25487), TP53(rs1042522) and cervical cancer

\begin{tabular}{|c|c|c|c|c|c|c|c|c|}
\hline \multirow[t]{2}{*}{ Variable } & \multirow[t]{2}{*}{ Groups } & \multicolumn{4}{|c|}{ Co-dominate model } & \multicolumn{3}{|c|}{ Recessive model } \\
\hline & & & $P$-value & OR & $95 \% \mathrm{Cl}$ & $P$-value & OR & $95 \% \mathrm{Cl}$ \\
\hline \multirow[t]{6}{*}{ rs 25487} & \multirow[t]{2}{*}{ Cases vs NC } & $\mathrm{G} / \mathrm{A}$ & \multirow[t]{2}{*}{$0.00^{*}$} & 2.00 & $1.14-3.50$ & \multirow[t]{2}{*}{$0.02^{*}$} & \multirow[t]{2}{*}{2.54} & \multirow[t]{2}{*}{$1.15-5.59$} \\
\hline & & $\mathrm{A} / \mathrm{A}$ & & 3.43 & $1.50-7.85$ & & & \\
\hline & \multirow[t]{2}{*}{ Cases vs OC } & $\mathrm{G} / \mathrm{A}$ & \multirow[t]{2}{*}{$0.03^{*}$} & 1.61 & $0.91-2.87$ & \multirow[t]{2}{*}{$0.03^{*}$} & \multirow[t]{2}{*}{2.40} & \multirow[t]{2}{*}{$1.06-5.46$} \\
\hline & & $\mathrm{A} / \mathrm{A}$ & & 3.00 & $1.26-7.10$ & & & \\
\hline & \multirow[t]{2}{*}{ NC vs OC } & $\mathrm{G} / \mathrm{A}$ & \multirow[t]{2}{*}{0.76} & 0.81 & $0.45-1.43$ & \multirow[t]{2}{*}{0.91} & \multirow[t]{2}{*}{0.95} & \multirow[t]{2}{*}{$0.37-2.43$} \\
\hline & & $\mathrm{A} / \mathrm{A}$ & & 0.87 & $0.33-2.30$ & & & \\
\hline \multirow[t]{6}{*}{ rs1042522 } & \multirow[t]{2}{*}{ Cases vs NC } & $\mathrm{G} / \mathrm{C}$ & \multirow[t]{2}{*}{0.54} & 0.73 & $0.41-1.29$ & \multirow[t]{2}{*}{0.82} & \multirow[t]{2}{*}{0.92} & \multirow[t]{2}{*}{$0.47-1.82$} \\
\hline & & $\mathrm{C} / \mathrm{C}$ & & 0.78 & $0.37-1.64$ & & & \\
\hline & \multirow[t]{2}{*}{ Cases vs OC } & $\mathrm{G} / \mathrm{C}$ & \multirow[t]{2}{*}{0.41} & 0.88 & $0.48-1.59$ & \multirow[t]{2}{*}{0.21} & \multirow[t]{2}{*}{0.66} & \multirow[t]{2}{*}{$0.34-1.27$} \\
\hline & & $\mathrm{C} / \mathrm{C}$ & & 0.61 & $0.30-1.27$ & & & \\
\hline & \multirow[t]{2}{*}{ NC vs OC } & $\mathrm{G} / \mathrm{C}$ & \multirow[t]{2}{*}{0.51} & 1.21 & $0.65-2.24$ & \multirow[t]{2}{*}{0.32} & 0.71 & $0.36-1.39$ \\
\hline & & $\mathrm{C} / \mathrm{C}$ & & 0.79 & $0.37-1.67$ & & & \\
\hline Variable & Groups & Dominar & & & Allele model & & & \\
\hline & & $P$-value & OR & $95 \% \mathrm{Cl}$ & $P$-value & OR & $95 \% \mathrm{Cl}$ & \\
\hline rs 25487 & Cases vs NC & $0.00^{*}$ & 2.30 & $\begin{array}{l}1.37- \\
3.86\end{array}$ & $0.00^{*}$ & 2.05 & $1.39-3.04$ & \\
\hline & Cases vs OC & $0.02^{*}$ & 1.88 & $\begin{array}{l}1.10- \\
3.22\end{array}$ & $0.00^{*}$ & 1.79 & $1.20-2.67$ & \\
\hline & NC vs OC & 0.47 & 0.82 & $\begin{array}{l}0.48- \\
1.40\end{array}$ & 0.53 & 0.87 & $0.57-1.34$ & \\
\hline rs 1042522 & Cases vs NC & 0.27 & 0.74 & $\begin{array}{l}0.43- \\
1.27\end{array}$ & 0.37 & 0.84 & $0.58-1.23$ & \\
\hline & Cases vs OC & 0.37 & 0.78 & $\begin{array}{l}0.45- \\
1.34\end{array}$ & 0.17 & 0.77 & $0.52-1.12$ & \\
\hline & NC vs OC & 0.87 & 1.05 & $\begin{array}{l}0.59- \\
1.86\end{array}$ & 0.64 & 0.91 & $0.62-1.34$ & \\
\hline
\end{tabular}

OR Odd ratio, Cl Confidence interval, NC Negative controls, OC Elderly patients above the age of 80

*indicated $p$-value $<0.05$

effective as the three-factor model that included rs121913483. Given this, we determined that the XRCC1 rs25487 heterozygote genotype combined with the TP53 rs1042522 heterozygote genotype was associated with an almost 4-fold (cases vs. negative controls) or 17 -fold (cases vs. elderly group) increase in cervical cancer risk (cases vs. negative controls: $\mathrm{OR}=4.63$, $95 \% \mathrm{CI}=1.83-11.75, p=0.00$; cases vs. elderly group: $\mathrm{OR}=17.61,95 \% \mathrm{CI}=4.34-71.50, p=0.00)$.

\section{Discussion}

Three SNPs were selected using text mining and bioinformatics, and they included FGFR3 rs121913483, TP53 rs1042522, and XRCC1 rs25487. In our current study, we found that no "C" allele of FGFR3 rs121913483 exists in any of our experimental groups. The genotype frequency of the TP53 rs1042522 polymorphism exhibited no obvious relationship to cervical cancer risk based on the frequency distribution of genotypes as indicated by the results from our logistic regression analysis. The "A" allele of rs 25487 was considered as a leading allele for an increased risk of cervical cancer, as there is a significant association of $X R C C 1$ gene polymorphism with cervical cancer. Additionally, the risk for cervical cancer was particularly high when TP53 and XRCC1 heterozygotes existed simultaneously. The risk of cervical cancer was 17 -fold compared with that of our elderly group.

The FGFR3 gene, a member of the tyrosine protein kinase family, is located on chromosome 4p16.3. This gene is primarily involved in bone development and osteogenesis [26]. Mutations of FGFR3 were reported in 3 out of 12 primary French cervical carcinomas [18]. In contrast, these mutations were not found in samples taken from Norwegian patients [19]. The genetic contribution of FGFR3 to cervical cancer risk was further investigated in the Chinese population. We found no mutation of FGFR3 in any groups used for our study. It is likely that these discrepancies are a result of racial differences and genetic background diversity. 
Table 3 The gene - gene interaction of XRCC1 and TP53 in the cervical cancer group and the negative control group

\begin{tabular}{|c|c|c|c|c|c|c|c|c|}
\hline & B & SE & Wald & N & $P$ & OR & $95 \% \mathrm{Cl}$ & \\
\hline \multicolumn{9}{|l|}{ Recessive model } \\
\hline $\mathrm{XRCC1}$ & -0.15 & 0.88 & 0.03 & 1 & 0.86 & 0.86 & 0.15 & 4.79 \\
\hline Tp53 & 0.29 & 0.89 & 0.11 & 1 & 0.75 & 1.33 & 0.24 & 7.56 \\
\hline Tp53-GG/GC by XRCC1-GG/GA & -0.06 & 0.96 & 0.00 & 1 & 0.95 & 0.95 & 0.15 & 6.16 \\
\hline 常数 & 0 & 0.82 & 0 & 1 & 1 & 1 & & \\
\hline \multicolumn{9}{|l|}{ Additive model } \\
\hline Tp53 & & & 7.71 & 2 & $0.02^{*}$ & & & \\
\hline Tp53-GC & -1.10 & 0.40 & 7.69 & 1 & $0.01^{*}$ & 0.33 & 0.15 & 0.72 \\
\hline Tp53-CC & -0.41 & 0.51 & 0.64 & 1 & 0.42 & 0.67 & 0.25 & 1.80 \\
\hline Tp53* XRCC1 & & & 10.49 & 4 & $0.03^{*}$ & & & \\
\hline Tp53-GC by XRCC1-GA & 1.53 & 0.48 & 10.43 & 1 & $0.00^{*}$ & 4.63 & 1.83 & 11.75 \\
\hline Tp53-GC by XRCC1-AA & 0.80 & 0.58 & 1.93 & 1 & 0.17 & 2.23 & 0.72 & 6.92 \\
\hline Tp53-CC by XRCC1-GA & -0.10 & 0.64 & 0.02 & 1 & 0.88 & 0.91 & 0.26 & 3.20 \\
\hline Tp53-CC by XRCC1-AA & 0.11 & 0.94 & 0.01 & 1 & 0.91 & 1.11 & 0.18 & 6.97 \\
\hline 常数 & 0.30 & 0.22 & 1.93 & 1 & 0.17 & 1.35 & & \\
\hline \multicolumn{9}{|l|}{ Dominant model } \\
\hline XRCC1-GA/AA & 0.71 & 0.27 & 6.84 & 1 & $0.01^{*}$ & 2.03 & 1.20 & 3.46 \\
\hline Tp53-GC/CC & -0.46 & 0.28 & 2.69 & 1 & 0.10 & 0.63 & 0.37 & 1.09 \\
\hline 常数 & -0.02 & 0.25 & 0.01 & 1 & 0.93 & 0.98 & & \\
\hline
\end{tabular}

*indicated $p$-value $<0.05$

$X R C C 1$ is a $33 \mathrm{~kb}$ gene located at chromosome 19q13.2-13.3. The encoded protein acts as a scaffolding protein for a number of repair enzymes and functions in enzymatic follow-up steps during DNA repair $[27,28]$. The XRCC1 protein has been reported to be involved in single-strand break repair, base excision repair, and nucleotide excision repair [29]. A polymorphic marker (rs25487) is located in exon 10 of this gene and has been examined for possible association with several malignancies, including cervical cancer [30, 31]. Our findings confirm the association of XRCC1 rs25487 with an elevated risk for cervical cancer.

The TP53 gene, located on chromosome 17p13.1, encodes a known tumor suppressor [32]. This gene product prevents genomic mutations and functions to conserve gene stability [33]. The relationship between TP53 and susceptibility to cervical cancer has been contradictory in previous studies. A study by Storey suggested that rs1042522 significantly enhanced the risk for cervical cancer $(\mathrm{OR}=7.4,95 \% \mathrm{CI}=2.1-29.4)$ [15], which was consistent with results from a study by Klug $(\mathrm{OR}=2.2,95 \% \mathrm{CI}=0.6-7.6)$ [34]. Contrary to these observations, the results of a study by Rosenthal did not find positive correlation between rs1042522 and cervical cancer risk [35]. Our study uses a larger samples size to support the findings of Rosenthal and also clarifies the interaction between XRCC1 and TP53 in influencing cervical cancer risk in China. It is likely that the inconsistency in population molecular genetics studies on the association between TP53 and cervical carcinoma is due in part to differences in the status and intensity of HPV infection and mutation rates of this virus in diverse regions. HPV infection and TP53 mutation are not independent high-risk factors for cervical cancer, but TP53 does promote CIN progression to cervical cancer. The interaction of genetic, intrinsic, and environmental factors is causally linked to the occurrence and development of cervical cancer.

Our results highlight the role of heterozygote rs25487 and rs1042522 variants in the susceptibility to cervical cancer within the Chinese southwestern population. It must be noted, however, that no obvious interaction between the minor alleles was detected when analyzing the cervical cancer group. We speculate that this phenomenon may result from the high lethality rate associated with the minor allele that may prevent significant results from being derived from data analysis of small sample pools. Of our samples, 31.71\% (negative control group: 9.76, elderly patients: 7.32 , cases group: 14.63) simultaneously exhibit an "A" allele of XRCC1 and a "C" allele of TP53. There were only $7 / 328$ (2.13\%) subjects exhibiting minor frequency in both the XRCC1 and TP53 genes. Additionally, differences in HPV infection 
Table 4 The gene - gene interaction of XRCC1 and TP53 in the cervical cancer group and the elderly patients above the age of 80 group

\begin{tabular}{|c|c|c|c|c|c|c|c|c|}
\hline & B & SE & Wald & N & $P$ & OR & $95 \% \mathrm{Cl}$ & \\
\hline \multicolumn{9}{|l|}{ Recessive model } \\
\hline Tp53-GG/GC & 1.34 & 0.55 & 5.85 & 1 & $0.02^{*}$ & 3.81 & 1.29 & 11.26 \\
\hline Tp53-GG/GC by XRCC1-GG/GA & -1.07 & 0.49 & 4.68 & 1 & $0.03^{*}$ & 0.34 & 0.13 & 0.90 \\
\hline 常数 & -0.13 & 0.30 & 0.20 & 1 & 0.66 & 0.88 & & \\
\hline \multicolumn{9}{|l|}{ Additive model } \\
\hline XRCC1 & & & 5.58 & 2 & 0.06 & & & \\
\hline XRCC1-GA & -0.85 & 0.49 & 3.03 & 1 & 0.08 & 0.43 & 0.16 & 1.11 \\
\hline XRCC1-AA & 0.69 & 0.74 & 0.87 & 1 & 0.35 & 1.99 & 0.47 & 8.42 \\
\hline Tp53 & & & 8.74 & 2 & $0.01^{*}$ & & & \\
\hline TP53-GC & -1.42 & 0.48 & 8.71 & 1 & $0.00^{*}$ & 0.24 & 0.10 & 0.62 \\
\hline TP53-CC & -0.81 & 0.57 & 2.07 & 1 & 0.15 & 0.44 & 0.15 & 1.34 \\
\hline Tp53 * XRCC1 & & & 17.22 & 4 & $0.00^{*}$ & & & \\
\hline TP53-GC by XRCC1-GA & 2.87 & 0.72 & 16.09 & 1 & $0.00^{*}$ & 17.61 & 4.34 & 71.50 \\
\hline TP53-GC by XRCC1-AA & 1.22 & 1.05 & 1.34 & 1 & 0.25 & 3.37 & 0.43 & 26.29 \\
\hline TP53-CC by XRCC1-GA & 0.95 & 0.81 & 1.37 & 1 & 0.24 & 2.57 & 0.53 & 12.51 \\
\hline TP53-CC by XRCC1-AA & -0.49 & 1.19 & 0.17 & 1 & 0.68 & 0.62 & 0.06 & 6.32 \\
\hline 常数 & 0.61 & 0.34 & 3.17 & 1 & 0.08 & 1.85 & & \\
\hline \multicolumn{9}{|l|}{ Dominant model } \\
\hline TP53-GC/CC & -0.96 & 0.35 & 7.66 & 1 & $0.01^{*}$ & 0.39 & 0.20 & 0.76 \\
\hline TP53-GC/CC by XRCC1-GA/AA & 1.29 & 0.37 & 12.54 & 1 & $0.00^{*}$ & 3.64 & 1.78 & 7.43 \\
\hline 常数 & 0.36 & 0.22 & 2.62 & 1 & 0.11 & 1.43 & & \\
\hline
\end{tabular}

*indicated $p$-value $<0.05$

history within our experimental group may have influenced our results. Cervical cancer risk is associated with high-risk HPV infection, and the penetrance of genetic high-risk factors is based on HPV infection [36]. Given this, identical status or intensity of HPV exposure within a given group is a prerequisite for statistical analysis. In clinical practice, it is difficult to meet this prerequisite as HPV infection rates and subtype distributions in various regions are different, with the exception of the cancer group [37, 38]. According to our clinical sample data, the HPV positive infection rate of our groups is $58 \%$. Based on the observed high HPV infection rates in Chongqing, we propose that mortality rates due to cervical cancer will increase when XRCC1 and TP53 are simultaneously mutated [37].

Table 5 The best model predicted ovarian cancer risk by GMDR

\begin{tabular}{lllll}
\hline Model & $\begin{array}{l}\text { Training } \\
\text { bal. acc }\end{array}$ & $\begin{array}{l}\text { Testing } \\
\text { bal. acc }\end{array}$ & $\begin{array}{l}\text { Sign test } \\
p \text { value }\end{array}$ & CV consistency \\
\hline XRCC1 & 0.58 & 0.58 & $7(0.17)$ & $10 / 10$ \\
XRCC1 TP53 & 0.66 & 0.63 & $10\left(0.00^{*}\right)$ & $10 / 10$ \\
XRCC1 TP53 FGFR3 & 0.66 & 0.63 & $10\left(0.00^{*}\right)$ & $10 / 10$
\end{tabular}

Data was analyzed by GMDR 0.9 with default settings *indicated $p$-value $<0.05$
Therefore, the influence of the SNP-SNP interaction between XRCC1 and TP53 in the context of cervical cancer is meaningful only when patients exhibit heterozygosity at the XRCC1 and TP53 loci (Tables 3 and 4).

Genetic testing combined with primary high-risk HPV testing has the potential to reduce the morbidity and mortality associated with cervical cancer. Based on our data, clinicians will gain critical insight into the mechanisms underlying the development of cervical cancer to provide novel approaches for the treatment of this disease.

\section{Conclusions}

Our novel approach of using an elderly control group (>80 yrs) with no history of cervical cancer allowed us to confirm a significant association between two SNPs, XRCC1 rs25487 and TP53 rs1042522, and the development of cervical cancer within the southwestern Chinese population. Additionally, we demonstrate the novel finding that no mutation of FGFR3 exists in the southwestern Chinese population. Finally, we clarify the inconsistent conclusions regarding the relationship between TP53 and cervical cancer by using a population molecular genetics approach. 


\section{Additional files}

Additional file 1: The inclusion and exclusion criteria of subjects. (DOCX $15 \mathrm{~kb}$ )

Additional file 2: Patient demographics and clinical characteristics of patients studied. (DOCX $15 \mathrm{~kb}$ )

Additional file 3: MAMA-PCR and Sanger sequencing for gene typing. (BMP $8580 \mathrm{~kb}$ )

\section{Abbreviations}

BER: Base excision repair; Cl: Confidence interval; FGFR3: Fibroblast growth factor receptor 3; GMDR: Generalized multifactor dimensionality reduction; HPV: Human papillomavirus; HWE: Hardy-Weinberg equilibrium; MAMAPC: Mutation analysis of mismatch amplification; OR: Odds ratio; SD: Standard deviation; SNP-SNP: Single nucleotide polymorphisms-single nucleotide polymorphisms; STD: Sexually transmitted disease; TP53: Tumor protein p53. XRCC1: $X$-ray repair cross complementing $1 ; X^{2}$ : Chi-square

\section{Acknowledgements}

We thank all patients for their participation in this study. We would also like to express our gratitude to the First Affiliated Hospital of Chongqing Medical University (Chongqing, China) and Dr. Peng Luo for his help in collecting peripheral blood samples.

\section{Funding}

This work was supported by the National Natural Science Foundation of China (20803098). The National Natural Science Foundation of China assists in study design and in writing the manuscript. It also assists in collection, analysis, and interpretation of data.

\section{Availability of data and materials}

The datasets used and/or analyzed during the current study are available from the corresponding author upon reasonable request.

\section{Authors' contributions}

JZ conceived and designed the study. GCL, YFZ, and XCS collected samples and physical data. GCL performed the statistical analysis and drafted the report. All authors reviewed and approved the final manuscript.

\section{Ethics approval and consent to participate}

This study was approved by the Institutional Review Board of the Scientific and Research Institute of Molecular Biology and Medicine at Chongqing Medical University (Protocol \#7, January 8, 2016). We obtained written informed consent from all study participants.

\section{Consent for publication}

Not applicable.

\section{Competing interests}

The authors declare that they have no competing interests.

\section{Publisher's Note}

Springer Nature remains neutral with regard to jurisdictional claims in published maps and institutional affiliations.

Received: 15 June 2018 Accepted: 28 November 2018

Published online: 07 January 2019

\section{References}

1. McGuire S. World Cancer Report 2014. Geneva, Switzerland: World Health Organization, International Agency for Research on Cancer, WHO Press, 2015. Adv Nutr. 2016;7(2):418-9.

2. Ferlay J, Soerjomataram I, Dikshit R, Eser S, Mathers C, Rebelo M, Parkin DM, Forman D, Bray F. Cancer incidence and mortality worldwide: sources, methods and major patterns in GLOBOCAN 2012. Int J Cancer. 2015;136(5):E359-86.

3. Schiffman MH, Bauer HM, Hoover RN, Glass AG, Cadell DM, Rush BB, Scott DR, Sherman ME, Kurman RJ, Wacholder S, et al. Epidemiologic evidence showing that human papillomavirus infection causes most cervical intraepithelial neoplasia. J Natl Cancer Inst. 1993;85(12):958-64.
4. Walboomers JM, Jacobs MV, Manos MM, Bosch FX, Kummer JA, Shah KV, Snijders PJ, Peto J, Meijer CJ, Munoz N. Human papillomavirus is a necessary cause of invasive cervical cancer worldwide. J Pathol. 1999;189(1):12-9.

5. Ho GY, Bierman R, Beardsley L, Chang CJ, Burk RD. Natural history of cervicovaginal papillomavirus infection in young women. N Engl J Med. 1998:338(7):423-8.

6. Hariri S, Unger ER, Sternberg M, Dunne EF, Swan D, Patel S, Markowitz LE. Prevalence of genital human papillomavirus among females in the United States, the National Health and Nutrition Examination Survey, 2003-2006. J Infect Dis. 2011;204(4):566-73.

7. Magnusson PK, Lichtenstein P, Gyllensten UB. Heritability of cervical tumours. Int J Cancer. 2000;88(5):698-701.

8. Kang S, Roh JW, Kim JW. Single nucleotide polymorphism: a new risk factor for endometrial cancer? Future Oncol. 2005;1(3):323-30.

9. Brumfield RT, Beerli P, Nickerson DA, Edwards SV. The utility of single nucleotide polymorphisms in inferences of population history. Trends Ecol Evol. 2003:18(5):249-56.

10. Mitani Y, Lezhava A, Kawai Y, Kikuchi T, Oguchi-Katayama A, Kogo Y, Itoh M, Miyagi T, Takakura H, Hoshi K, et al. Rapid SNP diagnostic using asymmetric isothermal amplification and a new mismatchsuppression technology. Nat Methods. 2007:4(3):257-62.

11. Alsbeih GA, Al-Harbi NM, Bin Judia SS, Khoja HA, Shoukri MM, Tulbah AM. Reduced rate of human papillomavirus infection and genetic overtransmission of TP53 72C polymorphic variant lower cervical cancer incidence. Cancer. 2017;123(13):2459-66.

12. Das Ghosh D, Mukhopadhyay I, Bhattacharya A, Roy Chowdhury R, Mandal NR, Roy S, Sengupta S. Impact of genetic variations and transcriptional alterations of HLA class I genes on cervical cancer pathogenesis. Int J Cancer. 2017;140(11):2498-508

13. Wu S, Wang S, Fu Y, Tang W, Jin H, Meng Q, Zhang C, Cui M, Cao X, Li X, et al. A novel mechanism of rs 763110 polymorphism contributing to cervical cancer risk by affecting the binding affinity of C/EBPbeta and OCT1 complex to chromatin. Int J Cancer. 2017;140(4):756-63.

14. Jiricny J, Marra G. DNA repair defects in colon cancer. Curr Opin Genet Dev. 2003;13(1):61-9.

15. Storey A, Thomas M, Kalita A, Harwood C, Gardiol D, Mantovani F, Breuer J, Leigh IM, Matlashewski G, Banks L. Role of a p53 polymorphism in the development of human papillomavirus-associated cancer. Nature. 1998; 393(6682):229-34

16. Josefsson AM, Magnusson PK, Ylitalo N, Quarforth-Tubbin P, Ponten J, Adami HO, Gyllensten UB. p53 polymorphism and risk of cervical cancer. Nature. 1998;396(6711):531 author reply 532

17. Yuan F, Sun R, Chen P, Liang Y, Ni S, Quan Y, Huang J, Zhang L, Gao L. Combined analysis of pri-miR-34b/c rs4938723 and TP53 Arg72Pro with cervical cancer risk. Tumour Biol. 2016:37(5):6267-73.

18. Cappellen D, De Oliveira C, Ricol D, de Medina S, Bourdin J, Sastre-Garau X, Chopin D, Thiery JP, Radvanyi F. Frequent activating mutations of FGFR3 in human bladder and cervix carcinomas. Nat Genet. 1999;23(1):18-20.

19. Dai H, Holm R, Kristensen GB, Abeler VM, Borresen-Dale AL, Helland A Fibroblast growth factor receptor 3 (FGFR3) - analyses of the S249C mutation and protein expression in primary cervical carcinomas. Anal Cell Pathol. 2001;23(2):45-9.

20. Franceschini A, Szklarczyk D, Frankild S, Kuhn M, Simonovic M, Roth A, Lin J, Minguez $P$, Bork $P$, von Mering $C$, et al. STRING v9.1: protein-protein interaction networks, with increased coverage and integration. Nucleic Acids Res. 2013;41(Database issue):D808-15.

21. Balsa-Canto E, Henriques D, Gabor A, Banga JR. AMIGO2, a toolbox for dynamic modeling, optimization and control in systems biology. Bioinformatics. 2016;32(21):3357-9.

22. Yu G, Wang LG, Han Y, He QY. clusterProfiler: an R package for comparing biological themes among gene clusters. OMICS. 2012; 16(5):284-7.

23. Zhu Z, Tong X, Zhu Z, Liang M, Cui W, Su K, Li MD, Zhu J. Development of GMDR-GPU for gene-gene interaction analysis and its application to WTCCC GWAS data for type 2 diabetes. PLoS One. 2013;8(4):e61943.

24. Cheng XD, Lu WG, Ye F, Wan XY, Xie X. The association of XRCC1 gene single nucleotide polymorphisms with response to neoadjuvant chemotherapy in locally advanced cervical carcinoma. J Exp Clin Cancer Res. 2009;28:91.

25. Niwa $Y$, Matsuo $K$, Ito $H$, Hirose $K$, Tajima K, Nakanishi T, Nawa A, Kuzuya K, Tamakoshi A, Hamajima N. Association of XRCC1 Arg399GIn and OGG1 
Ser326Cys polymorphisms with the risk of cervical cancer in Japanese subjects. Gynecol Oncol. 2005;99(1):43-9.

26. Kelleher FC, O'Sullivan $H$, Smyth E, McDermott R, Viterbo A. Fibroblast growth factor receptors, developmental corruption and malignant disease. Carcinogenesis. 2013;34(10):2198-205.

27. Caldecott KW. Single-strand break repair and genetic disease. Nat Rev Genet. 2008;9(8):619-31.

28. Caldecott KW. XRCC1 and DNA strand break repair. DNA Repair (Amst). 2003;2(9):955-69.

29. London RE. The structural basis of XRCC1-mediated DNA repair. DNA Repair (Amst). 2015;30:90-103.

30. Mei J, Duan HX, Wang LL, Yang S, Lu JQ, Shi TY, Zhao Y. XRCC1 polymorphisms and cervical cancer risk: an updated meta-analysis. Tumour Biol. 2014;35(2):1221-31.

31. Li Y, Liu F, Tan SQ, Wang Y, Li SW. X-ray repair cross-complementing group 1 (XRCC1) genetic polymorphisms and cervical cancer risk: a huge systematic review and meta-analysis. PLoS One. 2012;7(9):e44441.

32. Surget S, Khoury MP, Bourdon JC. Uncovering the role of p53 splice variants in human malignancy: a clinical perspective. Onco Targets Ther. 2013;7:57-68

33. Bourdon JC, Fernandes K, Murray-Zmijewski F, Liu G, Diot A, Xirodimas DP, Saville MK, Lane DP. p53 isoforms can regulate p53 transcriptional activity. Genes Dev. 2005;19(18):2122-37.

34. Klug SJ, Wilmotte R, Santos C, Almonte M, Herrero R, Guerrero I, Caceres E, Peixoto-Guimaraes D, Lenoir G, Hainaut P, et al. TP53 polymorphism, HPV infection, and risk of cervical cancer. Cancer Epidemiol Biomarkers Prev. 2001;10(9):1009-12.

35. Rosenthal AN, Ryan A, Al-Jehani RM, Storey A, Harwood CA, Jacobs IJ. p53 codon 72 polymorphism and risk of cervical cancer in UK. Lancet. 1998; 352(9131):871-2

36. Saslow D, Solomon D, Lawson HW, Killackey M, Kulasingam SL, Cain J, Garcia FA, Moriarty AT, Waxman AG, Wilbur DC, et al. American Cancer Society, American Society for Colposcopy and Cervical Pathology, and American Society for Clinical Pathology screening guidelines for the prevention and early detection of cervical cancer. CA Cancer J Clin. 2012; 62(3):147-72.

37. Tang Y, Zheng L, Yang S, Li B, Su H, Zhang LP. Epidemiology and genotype distribution of human papillomavirus (HPV) in Southwest China: a crosssectional five years study in non-vaccinated women. Virol J. 2017;14(1):84.

38. Chen $X, X u H, X u$ W, Zeng W, Liu J, Wu Q, Zhao X, Jiang T. Prevalence and genotype distribution of human papillomavirus in 961,029 screening tests in southeastern China (Zhejiang Province) between 2011 and 2015. Sci Rep. 2017;7(1):14813.

Ready to submit your research? Choose BMC and benefit from:

- fast, convenient online submission

- thorough peer review by experienced researchers in your field

- rapid publication on acceptance

- support for research data, including large and complex data types

- gold Open Access which fosters wider collaboration and increased citations

- maximum visibility for your research: over $100 \mathrm{M}$ website views per year

At $\mathrm{BMC}$, research is always in progress.

Learn more biomedcentral.com/submissions 